\title{
Novel and promising approaches in COVID-19 treatment
}

\author{
Zahra ASEFY 1 (D), Hamid RASHIDZADEH 2 (D), Ali MOHAMMADI 2 (D), Mohammad CHAREHSAZ ${ }^{3 *}$ (D), \\ Hande SİPAHI 3 (D), Ahmet AYDIN 3 (D), Sinem HELVACIOĞLU 3 (D), Rovshan KHALILOV 4,5,6 (D), \\ Renad Ibragimovich ZHDANOV 5 (D), Hossein DANAFAR ${ }^{6}$ (D), Amir HASANZADEH ${ }^{1}$ (D), \\ Aziz EFTEKHARI $1,5 *$ (D)
}

1 Department of Pharmaceutical Toxicology, Maragheh University of Medical Sciences, Maragheh, Iran.

2 Zanjan Pharmaceutical Biotechnology Research Center, Zanjan University of Medical Sciences, Zanjan, Iran.

3 Department of Pharmaceutical Toxicology, Faculty of Pharmacy, Yeditepe University, İstanbul, Turkey.

4 Department of Biophysics and biochemistry, Baku State University, Baku, Azerbaijan.

5 Russian Institute for Advanced Study, Moscow State Pedagogical University, 1/1, Malaya Pirogovskaya St, Moscow, 119991 Russian Federation.

6 Institute of Radiation Problems, National Academy of Sciences of Azerbaijan, Baku, Azerbaijan.

* Corresponding Author. E-mail: mohammad.saz@yeditepe.edu.tr (M.C.); Tel. +90-538-643 5677.

* Corresponding Author. E-mail: eftekharia@tbzmed.ac.ir (A.E.); Tel. +989364655619.

Received: 30 July 2021 / Revised: 16 November 2021/ Accepted: 18 November 2021

\begin{abstract}
Novel coronavirus or severe acute respiratory syndrome coronavirus 2 (SARS-CoV-2) causes severe respiratory infectious disease, known as coronavirus disease-19 (COVID-19). Over the past few months, a considerable rise in the incidence rate and prevalence of COVID-19 infection have been witnessed. Considering the high disease burden and rapid spread of the COVID-19 and no effective treatment is currently existing, stem cells, engineered nanobiomaterials, natural killer cells based therapy, RNA metabolites and extracellular vesicles are promising alternatives to tackle devastating epidemic. This review spotlights the applications and potential of above-mentioned methods in the treatment of COVID-19.
\end{abstract}

KEYWORDS: Coronavirus; SARS-CoV-2; nano vaccine; ACE 2; extracellular vesicles.

\section{INTRODUCTION}

Coronavirus disease 2019 (COVID-19) is a viral infection with acute respiratory syndrome, which originated in Wuhan (China) and has been spread to almost every country in the World [1]. The virus is transmitted through close contact with infected people, as well as the contaminated objects of an infected person [2]. Severe acute respiratory syndrome coronavirus 2 (SARS-CoV-2), the third major pathogenic coronavirus after severe acute respiratory syndrome (SARS) and Middle East respiratory syndrome (MERS) in the past two decades, has been able to infect humans by crossing animal species. In general, alpha and betacoronaviruses mainly infect mammals and cause human and animal diseases. In contrast, gamma coronaviruses and delta coronaviruses mainly infect birds; however, some can also infect mammals. Alpha coronaviruses include various bat coronaviruses, rodent coronaviruses such as mice, and the epidemic of swine epidemic diarrhea. Beta coronaviruses include various rat coronaviruses and multiple bat coronaviruses. The virus appears to be caused by domestic animals, especially birds, including bats [3].

At-risk individuals include elderly people, people living with the patient, and health care personnel who are responsible for the care and treatment of these patients [4]. The incubation period of the disease is between 4-8 days and sometimes up to 14 days. The disease begins and develops with symptoms of the common cold, a fever of 38 degrees, muscle aches, and a dry cough. Pulmonary imaging in some patients shows symptoms of unilateral or bilateral pneumonia. Laboratory symptoms can include lymphopenia, decreased oxygen in the blood, and increased creatine phosphokinase (CPK) and lactate dehydrogenase $(\mathrm{LDH})$. Identifying the virus genome verified that it is a new type of coronavirus family [5]. New molecular methods of virus detection have been made possible in clinical specimens using reverse transcription-

How to cite this article: Asefy Z, Rashidzadeh H, Mohammadi A, Charehsaz M, Sipahi H, Aydın A, Helvacıoğlu S, Khalilov R, Zhdanov RI, Danafar H, Hasanzadeh A, Eftekhari A. Novel and promising approaches in COVID-19 treatment. J Res Pharm. 2021; 25(6): $772-784$. 
polymerase chain reaction (RT-PCR) within a few hours. Due to the different course of the disease in $5 \%$ of people with respiratory problems, it is necessary to use mechanical ventilation. Treatment with steroids and broad-spectrum antibiotics and antiviral drugs such as remdesevir are recommended in acute cases. It is recommended not to travel to high-risk areas to prevent the spread of the disease [6].

Regular control of body temperature for 10 days is recommended and in case of fever, more than $38^{\circ} \mathrm{C}$ should be referred to healthcare centers. Due to the high number of infections in the health care staff who have been in contact with patients, the awareness and serious attention of physicians and health care staff to the care and prevention points are necessary [7]. Table 1 represents different clinical manifestations of COVID-19.

Table 1. COVID-19 disease severity criteria.

\begin{tabular}{ll}
\hline Mild & $\begin{array}{l}\text { Clinical symptoms (high fever of } 38^{\circ} \mathrm{C} \text {, with or without cough, lack } \\
\text { of shortness of breath, shortness of breath, and absence of chronic } \\
\text { diseases), healthy lungs in imaging. }\end{array}$ \\
Medium & Fever, shortness of breath, and pneumonia in imaging \\
Critical & If any of the following are observed: \\
& $\begin{array}{l}\text { 1. Respiratory failure, need for mechanical ventilation or artificial } \\
\text { respiration } \\
\text { 2. Septic shock } \\
\text { 3. Extrapulmonary organ failure, transfer to the intensive care unit }\end{array}$
\end{tabular}

It can be argued that the new virus-induced pandemic has gradually overtaken the first to fourth phases of globalization in 2002, the fifth phase of which began in China in late December 2019 with extensive human transmission and has rapidly improved to the sixth phase [8]. In 1918, the re-emergence of the influenza virus H1N1 (A) caused catastrophic globalization. The virus entered humans and pigs simultaneously through birds, and there is even evidence that it was transmitted from humans to pig at that time [9]. The spell it out (OIV-S) virus has three genes common to the seasonal influenza virus H1N1 (A) and three genes common to the seasonal flu virus H3N2 (A) [10]. The history of the influenza virus H1N1 (A) has been recorded by multiple human-to-human transmission of the virus. Although sporadic cases of human-to-human transmission of the virus from pigs have been sufficiently pathogenic to cause clear clinical disease, very rarely have such cases been transmitted from humans who have contracted the disease from pigs to those around them [11]. In other words, although human-to-human transmission and the spread of the new virus required primary infection with pigs, the infection did not mean subsequent release and secondary attack in humans, and as long as the animal virus undergoes the necessary genetic changes [12]. It has not been seriously studied in humans, and only one exceptionally well-proven case has been proven in the military, even in which the ability to transmit from human to human is very limited.

Influenza virus H1N1 (A), which caused catastrophic globalization in the years 1918-19, has been living directly and indirectly in the human body and pigs, and by transmitting its genes to new viruses, it causes pandemics. One of the two unrelated strains of the swine virus is those who were exposed to pneumonia in 1918. Over the years, they have experienced several pandemics and epidemics. According to evidence, in 1918 a new virus probably originated in birds, which contained a total of eight new influenza genes and, after the globalization of human disease, was transmitted from human to pig and thus led to its longevity. It continues in nature and the virus that causes the new pandemic is one of its genetically shifted products. To better understand the mechanism of survival of this virus over the past century, it can be assumed that influenza A viruses, which have caused globalization and epidemics during this period, were not completely new viruses but each of them as one of eight genetic versions. The virus was introduced in 1918, and at any given time, one of them appear in the form of a new virus. It is worth noting that the mechanisms by which the bird flu virus crosses the barrier and causes infection in humans and other mammals, thus acting as a host for infected species or by transmitting human-to-human virus-causing viruses, continue to be vital.

Besides, properties such as infection, transmission, and viral virulence have been implicated by several genes that are not yet clearly identified, and it has been shown that an influenza virus has a gene for one of the hemagglutinins, the surface protein of the virus, and another gene encoding for one of the nine surface proteins. These proteins, which in turn facilitate the binding and release of the virus, play a key role not only 
in infecting host cells but also in triggering immune responses and reducing virus replication. It should be noted that although the combination of 16 hemagglutinin and 9 neuraminidase from bird flu viruses may produce 144 types of viruses with relatively different characteristics, such events have not yet occurred and only three combinations of $\mathrm{H} 3 \mathrm{~N} 2, \mathrm{H} 2 \mathrm{~N} 2$ or $\mathrm{H} 2 \mathrm{~N} 2, \mathrm{H} 1$ [13]. It could indicate that all genes need to be matched for the new virus to be completely successful. The antigenic shift in the H1N1 virus in 1918 led to the reemergence of the H2N2 virus in 1957.

\section{RECEPTOR OF CORONAVIRUS}

Genomic analysis showed that SARS-CoV-2 is approximately $80 \%$ similar to the SARS-CoV, the etiological agent of SARS. Angiotensin-converting enzyme 2 (ACE 2), the receptor for both SARS-CoV and SARS-CoV-2, was expressed in human airway epithelia and lung parenchyma as well as many other organs [14]. ACE 2, a zinc metalloprotease, is a protein sequence consists of 805 amino acids with two domains; the $\mathrm{N}$-terminal is a carboxypeptidase homologous to ACE and the C-terminal is homologous to collectrin and responsible for the trafficking of the neutral amino acid transporter B(0)AT1 to the plasma membrane of gut epithelial cells [15]. ACE 2 and its homologous ACE are two main components of the renin-angiotensin system, which is responsible for cardiovascular homeostasis, regulation of blood pressure, fluid, and electrolyte balance. After production of angiotensinogen in the liver, it is cleaved by renin to decapeptide angiotensin I, which is then converted into octapeptide angiotensin II by ACE [16]. Angiotensin II is a key peptide of the renin-angiotensin system and binds to angiotensin type 1 receptor, thus mediates vasoconstriction, the release of vasopressin and aldosterone, renal sodium reabsorption, as well as inflammation and angiogenesis. On the other hand, ACE 2 acts as a negative regulator of the renin-angiotensin system by hydrolyzing angiotensin II to angiotensin 1-7, which acts via the MAS receptor to promote vasodilation and hypotension [17]. ACE 2 is found protective in acute lung injury and acute respiratory distress syndrome because of participating in inflammatory and fibrotic responses in diseases and assisting the absorption of essential amino acids in the intestine as a partner of amino acid transporters [15]. However, the ACE 2 receptor has a crucial role in facilitating the cellular entry of SARS-CoV-2 and SARS-CoV. As shown in Figure 1, SARS-CoV-2 consists of four structural proteins known as the S (spike), E (envelope), M (membrane), and $\mathrm{N}$ (nucleocapsid) proteins.

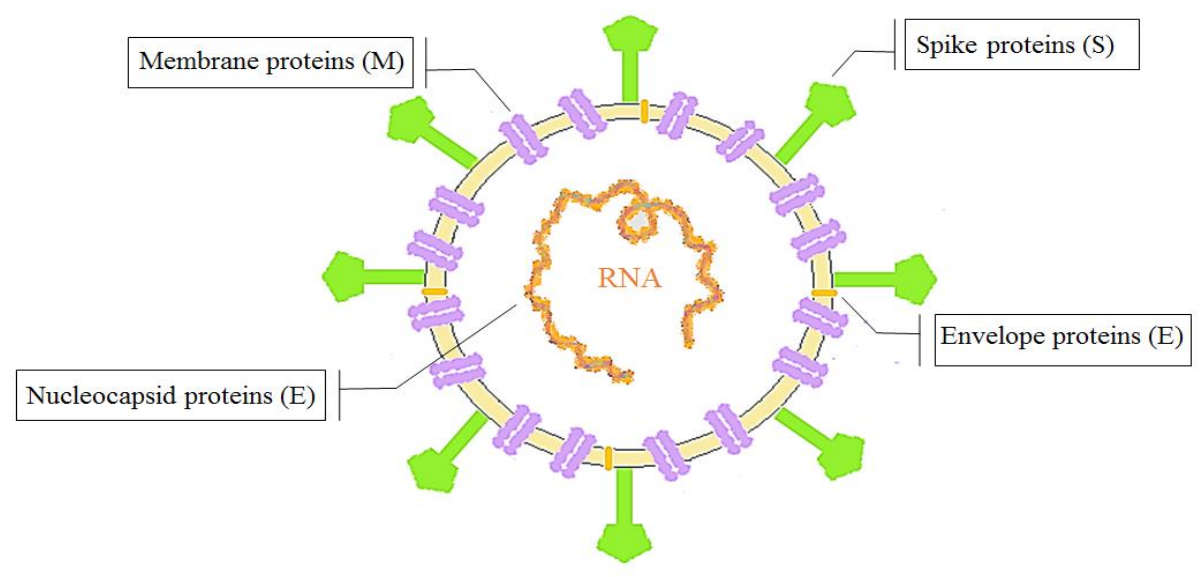

Figure 1. Four main structural proteins of COVID-19.

The S protein mediates coronavirus entry into host cells. It first binds to a receptor on the host cell surface through its S1 subunit and then fuses viral and host membranes through its S2 subunit [18]. Several studies revealed that SARS-CoV-2 uses ACE-2 as a cellular entry receptor. Zhou et al. showed that SARS-CoV2 could use ACE- 2 from humans, Chinese horseshoe bats, civet cats, and pigs to gain entry into ACE-2expressing HeLa cells [19]. Hoffmann et al. showed that treating of monkey kidney cell line which is known to permit SARS-CoV replication, with an Anti-ACE-2 antibody blocked entry of vesicular stomatitis virus (VSV) pseudotypes expressing the SARS-CoV-2 S protein (Figure 2) [20]. 


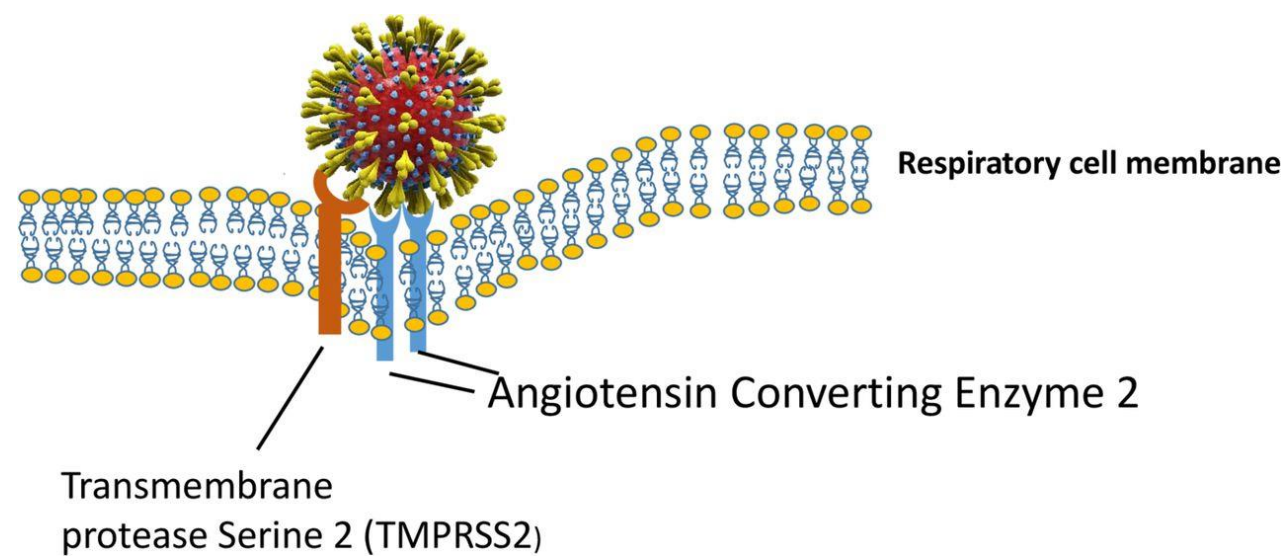

Figure 2. Angiotensin-converting enzyme 2 (ACE 2) as a cellular entry receptor for mediating infection by SARS-CoV-2. Reproduced with permission [20]. Copyright 2020, BMJ Publishing Group Ltd.

Furthermore, the higher affinity of the receptor-binding domain in S1 subunit of S protein of SARS$\mathrm{CoV}-2$ to the ACE 2 receptor than SARS-CoV, providing some explanation of the higher infectivity and transmissibility of SARS-CoV-2 compared to SARS-CoV [21].

\section{COMMONLY USED THERAPEUTICS AGAINST CORONAVIRUS INFECTION}

There are no specific antiviral drugs or vaccines against COVID-19 infection for potential therapy of humans till now [22]. Countries are having their own experiences to combat this epidemic. The best measure against the spreading of COVID-19 is to maintain social distance between persons. The treatment is symptomatic, and oxygen therapy represents the major treatment intervention for patients with severe infection. Mechanical ventilation may be necessary in cases of respiratory failure of patients. The commonly applied option is using existing drugs. Drugs used for COVID-19 treatment was summarized in Table 2.

Table 2. Drugs used for COVID-19 treatment according to clinical.gov.tr (Access date: 30.04.2020).

\begin{tabular}{|c|c|c|}
\hline Group & Drugs & Details \\
\hline \multirow[t]{8}{*}{ Antivirals Antimalarial } & Remdesivir & $\begin{array}{c}\text { Safety and antiviral } \\
\text { activity }\end{array}$ \\
\hline & Favipiravir & $\begin{array}{c}\text { Favipiravir }+ \\
\text { standart of care } \\
\text { versus standart of } \\
\text { care }\end{array}$ \\
\hline & \multirow[t]{6}{*}{ Hydroxychloroquine } & Hydroxychloroquine \\
\hline & & $\begin{array}{l}\text { Hydroxychloroquine } \\
+ \text { intravenous } \\
\text { famotidine versus } \\
\text { hydroxycloroquine }+ \\
\text { placebo }\end{array}$ \\
\hline & & $\begin{array}{c}\text { Hydroxychloroquine } \\
+ \\
\text { Lopinavir/ritonavir }\end{array}$ \\
\hline & & $\begin{array}{l}\text { Hydroxychloroquine } \\
\text { versus azithromycin }\end{array}$ \\
\hline & & $\begin{array}{c}\text { Hydroxychloroquine } \\
+ \\
\text { lopinavir/ritonavir } \\
+ \text { interferon- } \beta \text { la vs } \\
\text { interferon- } \beta \text { 1b }\end{array}$ \\
\hline & & $\begin{array}{l}\text { Hydroxychloroquine } \\
\text { + ivermectin versus }\end{array}$ \\
\hline
\end{tabular}




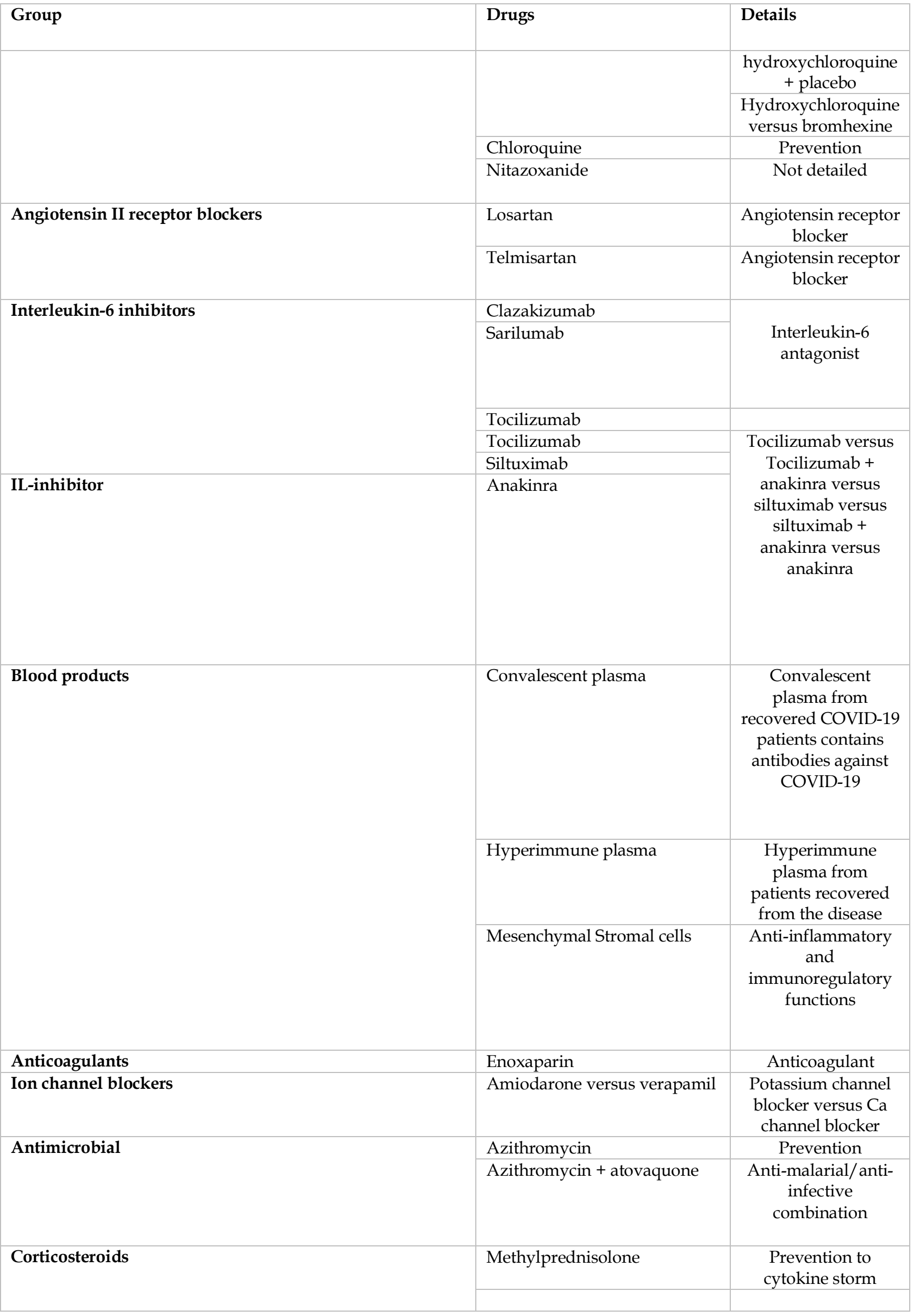




\begin{tabular}{|c|c|c|}
\hline Group & Drugs & Details \\
\hline & Dexamethasone & $\begin{array}{l}\text { Acute respiratory } \\
\text { distress syndrom }\end{array}$ \\
\hline \multirow[t]{5}{*}{ Immunomodulators } & Colchicine & Immunomodulation \\
\hline & Baricitinib & $\begin{array}{l}\text { Reduction in } \\
\text { cytokine release }\end{array}$ \\
\hline & Sargramostim & $\begin{array}{l}\text { A pleiotropic } \\
\text { cytokine }\end{array}$ \\
\hline & Sirolimus & $\begin{array}{c}\text { Immunosuppressive } \\
\text { agent }\end{array}$ \\
\hline & Isotretinoin & $\begin{array}{l}\text { Destructive effect of } \\
\text { interleukin-6 }\end{array}$ \\
\hline \multirow[t]{4}{*}{ Miscellaneous } & Dapagliflozin & $\begin{array}{c}\text { Respiratory, } \\
\text { cardiovascular and } \\
\text { kidney protection }\end{array}$ \\
\hline & Methylene blue & $\begin{array}{l}\text { Methylene blue, } \\
\text { vitamin C, N- } \\
\text { acetylcysteine }\end{array}$ \\
\hline & Sildenafil & Not detailed \\
\hline & Deferoxamine & $\begin{array}{c}\text { Standard treatment } \\
\text { regimens }+ \\
\text { intravenous } \\
\text { deferoxamine }\end{array}$ \\
\hline VPAC1 receptors & Aviptadil & $\begin{array}{l}\text { binds to VPAC1 } \\
\text { receptors on the } \\
\text { pulmonary Alveolar } \\
\text { Type II (ATII) cell }\end{array}$ \\
\hline Monoclonal antibody therapy & $\begin{array}{l}\text { Bamlanivimab-Etesevimab } \\
\text { Casirivimab-Imdevimab } \\
\text { Sotrovimab }\end{array}$ & $\begin{array}{l}\text { LY-CoV555 and LY- } \\
\text { CoV016(combination } \\
\text { of anti-spike } \\
\text { monoclonal } \\
\text { antibodies) } \\
\text { REGEN-COV (anti- } \\
\text { spike monoclonal } \\
\text { antibodies) }\end{array}$ \\
\hline
\end{tabular}

Due to time-consuming studies to discover new drugs against any type of disease, retargeting of available drugs stands applicable and logical to find an efficient drug in a short time. With this attempt, antimalarial drugs including hydroxychloroquine were used against COVID-19 and obtained positive results against this disease [23]. Existing antiviral drugs like nucleoside analogs and human immunodeficiency virus (HIV)-protease inhibitors that could attenuate virus infection until the specific antiviral becomes available [22]. During this COVID-19 outbreak, available antiviral drugs were used in 75 patients. The course of treatment included twice a day oral administration of $75 \mathrm{mg}$ oseltamivir, $500 \mathrm{mg}$ lopinavir, $500 \mathrm{mg}$ ritonavir, and the intravenous administration of ganciclovir for 3-14 days [23]. Results were satisfactory to combat COVID-19 infection to some extent. Another report showed that the broad-spectrum antiviral remdesivir and chloroquine are highly effective in the control of COVID-19 infection in vitro. These types of clinical experiences in different countries will add new information to the treatment protocols or change them. Favipiravir (FPV), a novel ribonucleic acid (RNA)-dependent RNA polymerase (RdRp) inhibitor, which is effective in the treatment of influenza and Ebola virus was applied to COVID-19 patients [24]. Interferon-alfa (IFN-alfa) by aerosol inhalation was added to that protocol. According to the results of that application, favipiravir showed better therapeutic outcomes on disease progression and viral clearance. Additional treatment protocols can be focused on the neutrophil attack during infections. Neutrophil accumulation in the lung during COVID-19 infections was reported. Neutrophils come to be infected areas to kill pathogens (bacteria, fungi, and viruses) by reactive oxygen species production and phagocytosis. It was proposed that neutrophils had another much less recognized properties to kill pathogens: the formation of neutrophil extracellular traps (NETs) [25]. This structure entraps pathogens. This formation produces mucous in the lungs which deteriorate the gas exchange 
in the alveolar space. Therapeutic applications with a different mechanism of action which focuses on this area will be available after necessary clinical trials and clinical experiences such as gasdermin D inhibitors, colchicine, recombinant DNase I, anakinra, canakinumab, and rilonacept. Mesenchymal stem cells (MSCs) therapy is another application to treat respiratory diseases. It has immunomodulatory and anti-inflammatory properties. There are 17 completed clinical studies about the use of MSCs in respiratory diseases, and also more than 70 trials are registered in this area. Bone marrow, umbilical cord, umbilical cord blood, Wharton's jelly, menstrual blood, dental pulp, and commercial MSCs are the important MSC sources [26]. MSCs used to treat COVID-19 have a great attention for clinicians. MSCs alone or in combination with another treatment may be useful to treat COVID-19 patients. Since no treatment is approved yet, new alternative treatment methods continue to be explored rapidly. One of these methods is a treatment approach with convalescent plasma which is collected from the liquid part of the blood of patients collected from individuals who have recovered from COVID-19. Some findings are indicating that antibodies in the recovering patient blood against the virus might help in combating the disease. Therefore, FDA has issued guidance on the administration and study of investigational convalescent plasma [27]. Although the safety and efficacy data are not yet sufficient, $[28,29]$ according to preliminary data showed that the administration of convalescent plasma transfusion to five COVID-19 positive patients with SARS resulted in improved clinical condition [30].

Antibiotic treatments are also suggested to be effective in patients with viral pneumonia who developed a secondary bacterial infection, although this complication is reported to be uncommon early on in the course of COVID-19 pneumonia. In a clinical trial in France, azithromycin was reported to be more efficient for virus elimination when added to hydroxychloroquine, larger sample sizes are needed to confirm the drug combination is effective [23]. According to other clinical study results, high-dosage chloroquine alone and/or combination with azithromycin and oseltamivir is not recommended for critically ill patients with COVID-19 due to potential safety hazards [31]. Millán-Oñate et al. reported a successful recovery in a patient with confirmed COVID-19 pneumonia after treatment with chloroquine and clarithromycin [32]. There are also claims that antibiotic therapy especially in the lack of bacterial infection could lead to antibiotic-induced inflammatory storm and septic shock in COVID-19 disease, although the exact pathophysiology of septic shock in these patients is still unclear [33].

Relief Therapeutics and American company Neuro RX have discovered a new drug for COVID-19 disease that has been very successful in clinical trials. This drug is called "RLF-100" or "Aveptadil" and it can treat acute cases of COVID-19 virus in three days. Previously, Food and Drug Administration (FDA) in June approved drug administration in emergencies to treat acute respiratory conditions in subjects with coronavirus.

The coagulation cascade is also affected during COVID-19 disease. Undiagnosed pulmonary embolism and microthrombi were reported in the pathophysiology of these patients. Several pro-coagulant factors including factor VIII and fibrinogen can be associated with reported thromboembolic cases. In light of these findings, treatment protocols of COVID-19 patients are being updated to include anticoagulant therapy [34].

Another approach is in silico method to estimate the drug candidate molecules that can be used in treatment by computer methods [35]. According to a repurposing method, an approved anti-cancer drug carfilzomib, and a synthetic halogenated tetracycline antibiotic elbasvir were identified to have the best inhibitory activities against SARS-CoV-2 main protease respectively.

\section{STEM CELLS AS COVID-19 NEW THERAPEUTIC PROTOCOL}

Studies revealed that stem cell administrations in patients under 85 progress COVID-19 subjects recovery time two-fold and have high efficiency approximately in all subjects [36].

Stem cells have an antimicrobial activity that accelerates tissue regeneration, lung repair, and other organs. Stem cells repair respiratory system damaged tissues due to their outstanding ability to regenerate and repair damaged tissues. Indeed, this therapeutic protocol approach upregulates immune response and reverses COVID-19 dangerous complications. Acute respiratory distress syndrome is developed in COVID-19 subjects [37]. In a study approved by Miami University, some subjects were involved in stem cell therapy twice daily and some were involved in a placebo study. The recovery rate of patients in the control group (who received stem cells) was $91 \%$ and in patients in the placebo group was $42 \%$. The only person who died despite receiving treatment was over 85 years old. Researchers also discovered that patients who received stem cell therapy have recovery. More than half of them who received required doses within two weeks left the hospital. 
Also, one month after receiving treatment, $80 \%$ of the control group did not show any symptoms of the disease. According to Ricordi, 100 million stem cells were injected into each patient in 3 days. In total, each person in the control group received 200 million stem cells. Also, no side effects from receiving treatment were observed in patients (Figure 3) [38].

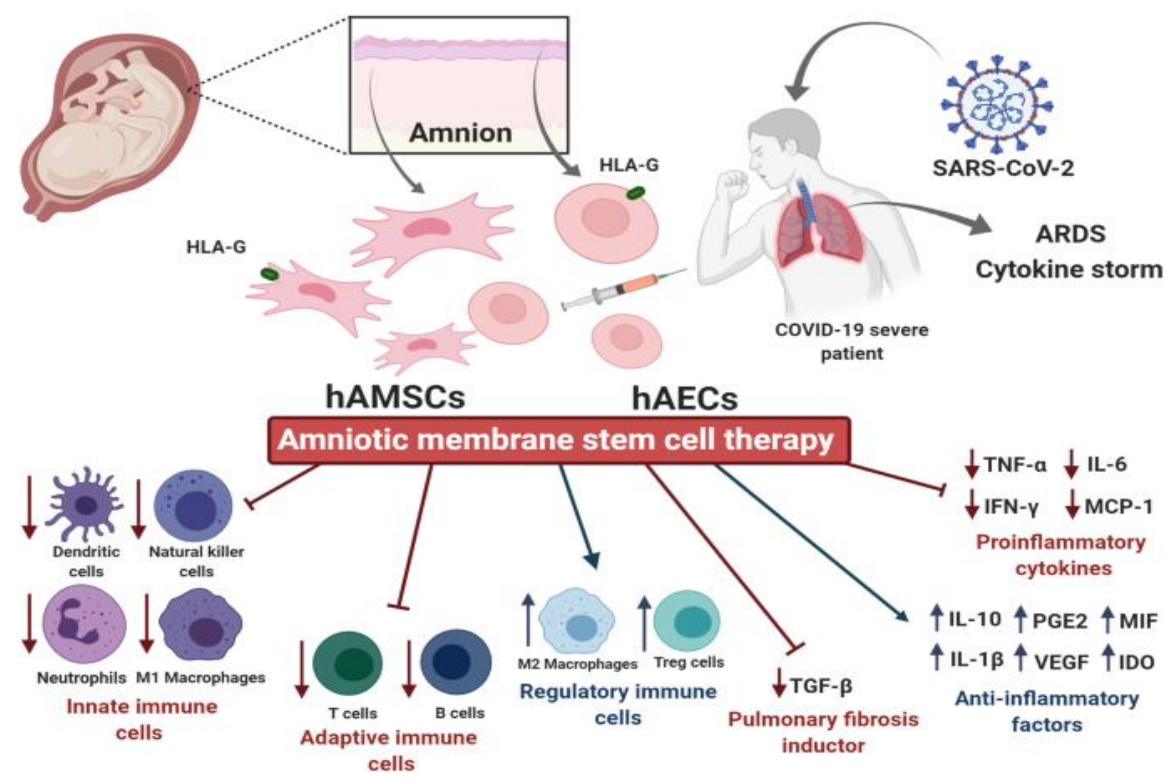

Figure 3. Stem cells isolated from the human placenta amnion include hAECs and hAMSCs. HAMSCs and hAECs have immunoregulatory, anti-inflammatory, and regenerative properties [38].

\section{NATURAL KILLER CELLS (NK CELLS) ADMINISTRATION}

Natural killer cells (NK cells) have also been studied as a therapeutic agent in some viral infections. Therefore, studies focused on cell therapy new protocols for immunodeficiency subjects. These patients, as well as stem cell transplant recipients, are at greater risk for complications from viral, fungal, or bacterial pathogens. Studies revealed that NK cells have high potencies to knock out target cells directly by cytotoxic molecules and apoptosis mediators. Similarly, these cells can upregulate the immune system by secreting various chemokines (Figure 4) [39].

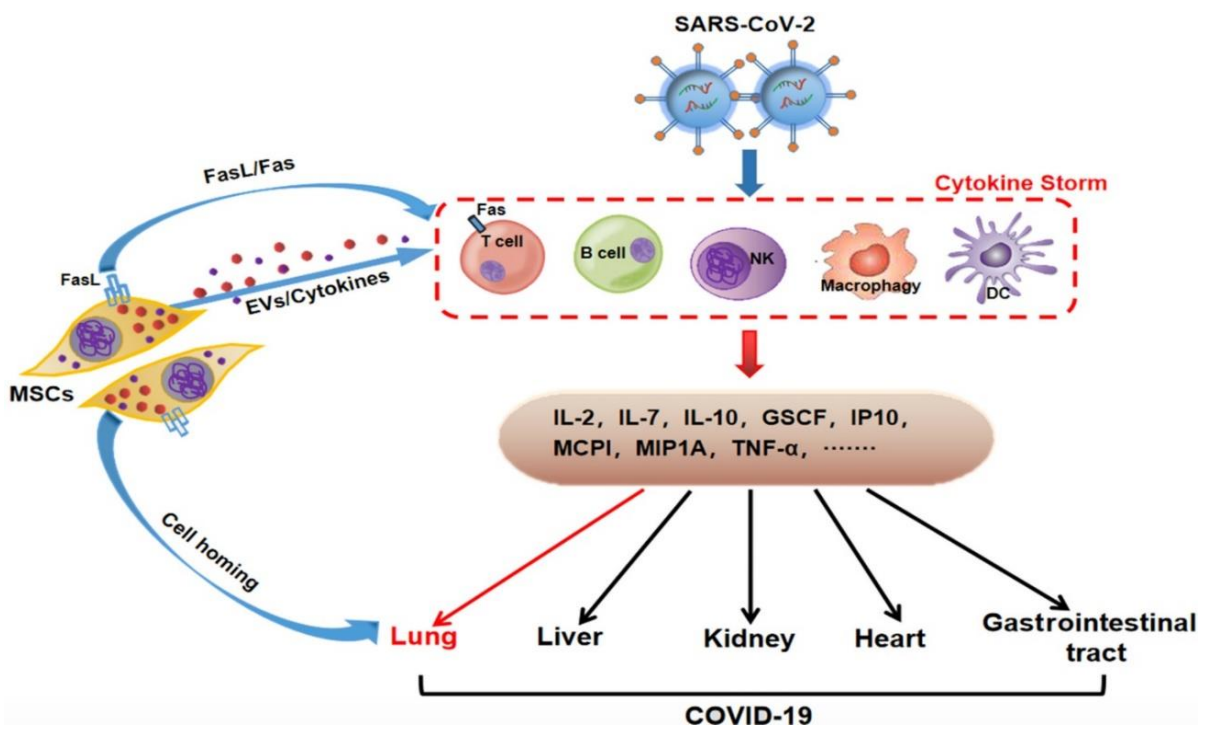

Figure 4. MSCs potential mechanism in treatment of severe COVID-19. Reproduced with permission [39]. Copyright 2020, John Wiley and Sons. 
Several studies have shown that genetic mutations, such as mutations affecting IL2RG, JAK3, and ADA genes, may lead to a decrease in NK cell count or NK cell dysfunction, leading to immunodeficiency syndromes. More interestingly, evidence suggests that different mechanisms stimulate NK cells during influenza infection. Following infection with the influenza virus, NK functional cells act as an intrinsic immune response. Animals and human clinical studies revealed that NK cells are key factors in antimicrobial immunotherapy [40]. Consequently, about COVID-19 subjects, numerous studies follow NK cells in COVID19 treatment. Phase II-A clinical study is currently underway at the MD Anderson Cancer Center to discover cord blood mesenchymal stem cells' safety and efficacy for patients with acute respiratory distress syndrome due to coronavirus infection. The benefits of cord blood-derived mesenchymal stem cells have been described in many previous articles and numerous research studies. In particular, umbilical cord blood mesenchymal stem cells from allogeneic donors are assumed to suppress inflammation and these cells affect tissue repair [41].

\section{NANO VACCINE IN COVID-19 TREATMENT}

Cytokine storm's main cause is the simultaneous inflammation and oxidative stress, occurrence which exacerbate each other. There is currently no effective drug to suppress this phenomenon, but nanoparticles can be considered effective therapeutic agents. Mineral nanoparticle administration has been broadly but it is required to study in which can beloved-19 subjects. Inorganic nanoparticles consist of a nanoscale mineral nucleus attached to an antigen that is applicable in COVID-19 vaccines. The major role of these mineral nanoparticles mainly associated with controllability and inflexible structure. For example, zirconium phosphate nano-drug co-therapy, which elevates COVID-19 drug's efficacy [42]. Zirconium phosphate will be a major factor in COVID-19 nano vaccines efficacy, and silver phosphate may be considered as antivirus because of antibiotic properties. Zirconium phosphate is not toxic, so it's safe for administration. Zirconium and silver nanoparticles inhibit virus ligands reactions with bronchial cells. Caracciolo $\mathrm{M}$ et al. reported that adenosine as natural anti-inflammatory nanoparticles drug delivery encapsulate with scallen, and is enriched with alpha-tocopherol. This method has been successfully confirmed in mice, and researchers indicate that this method can be considered in cytokine storm suppression. Adenosine is a potent anti-inflammatory metabolite that can be injected directly, that has severe side effects. Therefore, the use of nanoparticles administration to adenosine delivery which cytokine storm, can be more effective [43].

\section{COVID-19 RNA METABOLITES BASED THERAPY}

One of the biologically based therapies suggested for COVID-19 treatment is miRNAs, which regulate protein synthesis during translation. An analytical study identifying microRNAs complementary with COVID-19 viral genome, in UTR-3 and UTR-5, regions [44]. Studies indicate poor microRNAs completely complementary to viral genes. So siRNA based molecules application including siRNAs can be promising. Several studies have shown that miR-155 and miR-128 modulate innate immune responses against respiratory viruses. When these miRNAs are removed, the host is susceptible to these viruses. Silicon analysis of miRNAs in interaction with COVID-19 mRNA s revealed that there is a rearrangement of miR-214, miR-574-5p, and miR-17 which preclude virus replication. Another nucleic acid-based biological alternative that could potentially be administrated COVID-19 is RNA or DNA-based aptamers, which, comparable to antibodies have high target molecule affinity [45]. Recently, DNA-based aptamers efficacy with coronavirus capsid binding ability has been considered in order, and it has been proposed to COVID-19 diagnosis.

\section{EXTRACELLULAR VESICLES IN COVID-19 INFECTION TREATMENT}

Extracellular vesicles (EVs) are a heterogeneous group of membrane particles released from almost any cells that have a significant role in intercellular communication. Recently, mesenchymal stem cell-derived extracellular vesicles (MSC-EVs) have been shown to exert therapeutic aspects against COVID-19 infection [46].

EVs are released from a variety of cells and participate in intercellular communication by transporting biomolecules such as nucleic acids, proteins, and lipids to cells. Exosomes are EVs of 30 to 120 nanometers that are involved in a variety of pathological processes. COVID-19 infected cells release exosomes that interfere with infection through virus components such as miRNA and virus-derived proteins. Exosomes also contain receptors which susceptible to trap viruses [47]. 
Since December 2019, SARS-CoV-2 infection has become an emerging public health concern worldwide. Therefore, finding a safe and effective treatment method for severe COVID-19 infection is critical. Extracellular vesicles also may be involved in virus propagation because they carry receptors such as CD9 and ACE2, which make cells susceptible to the virus. COVID-19 virus components may be inserted into exosomes. Exosomebased strategies for treating COVID-19 infection may include exosome synthesis suppression and reabsorption, exosome therapy, exosome-based drug delivery systems, and exosome-based vaccines. Mesenchymal stem cells derived exosomes can suppress inflammation and repair lung cells, including endothelial and alveolar cells infected by COVID-19 infection. Molecular mechanisms discovery Evs associated with COVID-19 infection may provide virus integration into cells, proliferation to overcome its side effects. EVs transport RNAs and proteins to target cells which are both safe and have high efficiency. MSCEVs may be a new alternative to stem cell-based therapies. Vesicles have high potential in damaged tissue improvement as well as modulating immune responses have made these vesicles considered effective therapeutic agents in COVID-19 infections. Mesenchymal stem cells delivered exosomes can suppress inflammation and lung cells, improvement including endothelial and alveolar cells infected by COVID-19 virus [48].

\section{CONCLUSION AND FUTURE PROSPECTIVE}

Unfortunately, regardless of advances in medical science and global research effort to ascertain effective therapeutic agents against COVID-19, there is no approved therapeutic or vaccine for battling this viral pneumonia yet.

However, recently strong efforts have been applied to discover effective and promising approaches to face COVID-19 by many pharmaceutical companies and industries. Moreover, computational design and molecular docking simulation could be considered as very promising tools to discover new therapeutic agents with anti-COVID-19 properties.

Nanotechnology is a very broad and extensive field in which its application spread in almost all branches of science. With the aid of nanotechnology, devices or matters could be fabricated with novel chemical, physical, and biological properties. A considerable amount of literature has been published on nanotechnology-based medications for the treatment of viral infections. It is worth noting that COVID-19 as an invisible enemy can be initially treated with some already fabricated nano-based materials, which have been employed against previous SARS-CoV or similar viruses. Consequently, we believe that nanomedicine could play a profound role in not only advancing COVID-19 treatment but also in detection, prevention and vaccine development. In the absence of an effective vaccine or drastic and successfully applied recipe in battling COVID-19, the only immediate option to face this viral pneumonia is exploring the applicable antivirus agents from the off-label therapeutics such as blood component, antimalarials, antimicrobials, antivirals, corticosteroids, immunomodulatory agents.

The above-mentioned therapeutic approaches have been failed to address the successful elimination, eradication, treatment, and even controlling this viral pneumonia since the incidence, mortality, and morbidity associated with COVID-19 is increasing day by day and the situation is getting worse and uncontrollable. Understanding the involved receptors associated with COVID-19 and their mechanism and roles in transmission, as well as current evidence in using these therapeutics, could guide researchers to identify the most appropriate regimen to cure infected patients.

Author contributions: Concept - A.E., M.C.; Design - Z.A., H.R., A.M., M.C., H.S., A.A., S.H., R.K., R.I.Z., H.D., A.H., A.E.; Supervision - A.E.; Resources - Z.A., H.R., A.M., M.C., H.S., A.A., S.H., R.K., R.I.Z., H.D., A.H., A.E.; Materials Z.A., H.R., A.M., M.C., H.S., A.A., S.H., R.K., R.I.Z., H.D., A.H., A.E.; Data Collection and/or Processing - Z.A., H.R., A.M., M.C., H.S., A.A., S.H., R.K., R.I.Z., H.D., A.H., A.E.; Analysis and/or Interpretation - Z.A., H.R., A.M., M.C., H.S., A.A., S.H., R.K., R.I.Z., H.D., A.H., A.E.; Literature Search - Z.A., H.R., A.M., M.C., H.S., A.A., S.H., R.K., R.I.Z., H.D., A.H., A.E.; Writing - Z.A., H.R., A.M., M.C., H.S., A.A., S.H., R.K., R.I.Z., H.D., A.H., A.E.; Critical Reviews - Z.A., H.R., A.M., M.C., H.S., A.A., S.H., R.K., R.I.Z., H.D., A.H., A.E.

Conflict of interest statement: The authors declare no conflict of interest.

\section{REFERENCES}

[1] Khalilov R, Hosainzadegan M, Eftekhari A, Nasibova A, Hasanzadeh A, Vahedi P, Hosain Zadegan H. Overview of the environmental distribution, resistance, mortality, and genetic diversity of new coronavirus (COVID-19). Adv Biol Earth Sci. 2020; 5: 7-12. 
[2] Dong E, Du H, Gardner L. An interactive web-based dashboard to track COVID-19 in real time. Lancet Infect Dis. 2020; 20(5): 533-534. [CrossRef]

[3] Khalilov R, Hosainzadegan M, Eftekhari A, Hasanzadeh A, Zadegan HH, Nasibova A. Necessity of different countries to deal with similar phenomena of COVID-19 coronavirus. Adv Biol Earth Sci. 2020;5:5-6.

[4] Chen H, Guo J, Wang C, Luo F, Yu X, Zhang W, Li J, Zhao D, Xu D, Gong Q, Liao J, Yang H, Hou W, Zhang Y. Clinical characteristics and intrauterine vertical transmission potential of COVID-19 infection in nine pregnant women: a retrospective review of medical records. Lancet. 2020; 395(10226): 809-815. [CrossRef]

[5] Mehta P, McAuley DF, Brown M, Sanchez E, Tattersall RS, Manson JJ; HLH Across Speciality Collaboration, UK. COVID-19: consider cytokine storm syndromes and immunosuppression. Lancet. 2020; 395(10229): 10331034. [CrossRef]

[6] Zu ZY, Jiang MD, Xu PP, Chen W, Ni QQ, Lu GM, Zhang LJ. Coronavirus Disease 2019 (COVID-19): A Perspective from China. Radiology. 2020; 296(2): E15-E25. [CrossRef]

[7] Wang Y, Wang Y, Chen Y, Qin Q. Unique epidemiological and clinical features of the emerging 2019 novel coronavirus pneumonia (COVID-19) implicate special control measures. J Med Virol. 2020; 92(6): 568-576. [CrossRef]

[8] Anderson RM, Heesterbeek H, Klinkenberg D, Hollingsworth TD. How will country-based mitigation measures influence the course of the COVID-19 epidemic? Lancet. 2020; 395(10228): 931-4. [CrossRef]

[9] Morens DM, Taubenberger JK, Fauci AS. The persistent legacy of the 1918 influenza virus. N Engl J Med. 2009; 361(3): 225-9. [CrossRef]

[10] Valette M, Allard JP, Aymard M, Millet V. Susceptibilities to rimantadine of influenza A/H1N1 and A/H3N2 viruses isolated during the epidemics of 1988 to 1989 and 1989 to 1990. Antimicrob Agents Chemother. 1993; 37(10): 2239-40. [CrossRef]

[11] Munster VJ, de Wit E, van den Brand JM, Herfst S, Schrauwen EJ, Bestebroer TM, van de Vijver D, Boucher CA, Koopmans M, Rimmelzwaan GF, Kuiken T, Osterhaus AD, Fouchier RA. Pathogenesis and transmission of swineorigin 2009 A(H1N1) influenza virus in ferrets. Science. 2009; 325(5939): 481-3. [CrossRef]

[12] Claas EC, de Jong JC, van Beek R, Rimmelzwaan GF, Osterhaus AD. Human influenza virus A/HongKong/156/97 (H5N1) infection. Vaccine. 1998; 16(9-10): 977-8. [CrossRef]

[13] Reid AH, Fanning TG, Janczewski TA, Taubenberger JK. Characterization of the 1918 "Spanish" influenza virus neuraminidase gene. Proc Natl Acad Sci U S A. 2000; 97(12): 6785-6790. [CrossRef]

[14] Jia HP, Look DC, Shi L, Hickey M, Pewe L, Netland J, Farzan M, Wohlford-Lenane C, Perlman S, McCray PB Jr. ACE2 receptor expression and severe acute respiratory syndrome coronavirus infection depend on differentiation of human airway epithelia. J Virol. 2005; 79(23): 14614-21. [CrossRef]

[15] Jiang M, Xue Z, Li Y, Liu H, Zeng S, Hao J. A soft X-ray activated lanthanide scintillator for controllable NO release and gas-sensitized cancer therapy. Nanoscale Horiz. 2020; 5, 268. [CrossRef]

[16] Ahmadian E, Pennefather PS, Eftekhari A, Heidari R, Eghbal MA. Role of renin-angiotensin system in liver diseases: an outline on the potential therapeutic points of intervention. Expert Rev Gastroenterol Hepatol. 2016;10(11):1279-88. [CrossRef]

[17] Kuba K, Imai Y, Ohto-Nakanishi T, Penninger JM. Trilogy of ACE2: a peptidase in the renin-angiotensin system, a SARS receptor, and a partner for amino acid transporters. Pharmacol Ther. 2010; 128(1): 119-28. [CrossRef]

[18] Walls AC, Park YJ, Tortorici MA, Wall A, McGuire AT, Veesler D. Structure, Function, and Antigenicity of the SARSCoV-2 Spike Glycoprotein. Cell. 2020; 181(2): 281-292.e6. [CrossRef]

[19] Zhou Y, Vedantham P, Lu K, Agudelo J, Carrion R Jr, Nunneley JW, Barnard D, Pöhlmann S, McKerrow JH, Renslo AR, Simmons G. Protease inhibitors targeting coronavirus and filovirus entry. Antiviral Res. 2015; 116: 7684. [CrossRef]

[20] Pillay TS. Gene of the month: the 2019-nCoV/SARS-CoV-2 novel coronavirus spike protein. J Clin Pathol. 2020; 73(7):366-9. [CrossRef]

[21] Xia S, Liu M, Wang C, Xu W, Lan Q, Feng S, Qi F, Bao L, Du L, Liu S, Qin C, Sun F, Shi Z, Zhu Y, Jiang S, Lu L. Inhibition of SARS-CoV-2 (previously 2019-nCoV) infection by a highly potent pan-coronavirus fusion inhibitor targeting its spike protein that harbors a high capacity to mediate membrane fusion. Cell Res. 2020; 30(4): 343355. [CrossRef]

[22] Rothan HA, Byrareddy SN. The epidemiology and pathogenesis of coronavirus disease (COVID-19) outbreak. J Autoimmun. 2020; 109: 102433. [CrossRef] 
[23] Gautret P, Lagier JC, Parola P, Hoang VT, Meddeb L, Mailhe M, Doudier B, Courjon J, Giordanengo V, Vieira VE, Tissot Dupont H, Honoré S, Colson P, Chabrière E, La Scola B, Rolain JM, Brouqui P, Raoult D. Hydroxychloroquine and azithromycin as a treatment of COVID-19: results of an open-label non-randomized clinical trial. Int J Antimicrob Agents. 2020; 56(1): 105949. [CrossRef]

[24] Cai Q, Yang M, Liu D, Chen J, Shu D, Xia J, Liao X, Gu Y, Cai Q, Yang Y, Shen C, Li X, Peng L, Huang D, Zhang J, Zhang S, Wang F, Liu J, Chen L, Chen S, Wang Z, Zhang Z, Cao R, Zhong W, Liu Y, Liu L. Experimental Treatment with Favipiravir for COVID-19: An Open-Label Control Study. Engineering (Beijing). 2020; 6(10): 11921198. [CrossRef]

[25] Barnes BJ, Adrover JM, Baxter-Stoltzfus A, Borczuk A, Cools-Lartigue J, Crawford JM, Daßler-Plenker J, Guerci P, Huynh C, Knight JS, Loda M, Looney MR, McAllister F, Rayes R, Renaud S, Rousseau S, Salvatore S, Schwartz RE, Spicer JD, Yost CC, Weber A, Zuo Y, Egeblad M. Targeting potential drivers of COVID-19: Neutrophil extracellular traps. J Exp Med. 2020; 217(6): e20200652. [CrossRef]

[26] Golchin A, Seyedjafari E, Ardeshirylajimi A. Mesenchymal Stem Cell Therapy for COVID-19: Present or Future. Stem Cell Rev Rep. 2020; 6(3): 427-433. [CrossRef]

[27] Focosi D, Anderson AO, Tang JW, Tuccori M. Convalescent Plasma Therapy for COVID-19: State of the Art. Clin Microbiol Rev. 2020; 33(4): e00072-20. [CrossRef]

[28] Roback JD, Guarner J. Convalescent Plasma to Treat COVID-19: Possibilities and Challenges. JAMA. 2020; 323(16): 1561-1562. [CrossRef]

[29] Zhao Q, He Y. Challenges of Convalescent Plasma Therapy on COVID-19. J Clin Virol. 2020; 127: 104358. [CrossRef]

[30] Shen C, Wang Z, Zhao F, Yang Y, Li J, Yuan J, Wang F, Li D, Yang M, Xing L, Wei J, Xiao H, Yang Y, Qu J, Qing L, Chen L, Xu Z, Peng L, Li Y, Zheng H, Chen F, Huang K, Jiang Y, Liu D, Zhang Z, Liu Y, Liu L. Treatment of 5 Critically Ill Patients With COVID-19 With Convalescent Plasma. JAMA. 2020; 323(16): 1582-1589. [CrossRef]

[31] Borba MGS, Val FFA, Sampaio VS, Alexandre MAA, Melo GC, Brito M, Mourão MPG, Brito-Sousa JD, Baía-da-Silva D, Guerra MVF, Hajjar LA, Pinto RC, Balieiro AAS, Pacheco AGF, Santos JDO Jr, Naveca FG, Xavier MS, Siqueira AM, Schwarzbold A, Croda J, Nogueira ML, Romero GAS, Bassat Q, Fontes CJ, Albuquerque BC, Daniel-Ribeiro CT, Monteiro WM, Lacerda MVG; CloroCovid-19 Team. Effect of High vs Low Doses of Chloroquine Diphosphate as Adjunctive Therapy for Patients Hospitalized With Severe Acute Respiratory Syndrome Coronavirus 2 (SARS-CoV2) Infection: A Randomized Clinical Trial. JAMA Netw Open. 2020; 3(4): e208857. [CrossRef]

[32] Millán-Oñate J, Millan W, Mendoza LA, Sánchez CG, Fernandez-Suarez H, Bonilla-Aldana DK, Rodríguez-Morales AJ. Successful recovery of COVID-19 pneumonia in a patient from Colombia after receiving chloroquine and clarithromycin. Ann Clin Microbiol Antimicrob. 2020; 19(1): 16. [CrossRef]

[33] Hantoushzadeh S, Norooznezhad AH. Possible Cause of Inflammatory Storm and Septic Shock in Patients Diagnosed with (COVID-19). Arch Med Res. 2020; 51(4): 347-348. [CrossRef]

[34] Ranucci M, Ballotta A, Di Dedda U, Bayshnikova E, Dei Poli M, Resta M, Falco M, Albano G, Menicanti L. The procoagulant pattern of patients with COVID-19 acute respiratory distress syndrome. J Thromb Haemost. 2020; 18(7): 1747-1751. [CrossRef]

[35] Wang J. Fast Identification of Possible Drug Treatment of Coronavirus Disease-19 (COVID-19) through Computational Drug Repurposing Study. J Chem Inf Model. 2020; 60(6): 3277-3286. [CrossRef]

[36] Atluri S, Manchikanti L, Hirsch JA. Expanded Umbilical Cord Mesenchymal Stem Cells (UC-MSCs) as a Therapeutic Strategy in Managing Critically Ill COVID-19 Patients: The Case for Compassionate Use. Pain Physician. 2020; 23(2): E71-E83.

[37] Saldanha-Araujo F, Melgaço Garcez E, Silva-Carvalho AE, Carvalho JL. Mesenchymal Stem Cells: A New Piece in the Puzzle of COVID-19 Treatment. Front Immunol. 2020; 11: 1563. [CrossRef]

[38] Riedel RN, Pérez-Pérez A, Sánchez-Margalet V, Varone CL, Maymó JL. Stem cells and COVID-19: are the human amniotic cells a new hope for therapies against the SARS-CoV-2 virus?. Stem Cell Res Ther. 2021;12(1):1-9. [CrossRef]

[39] Ji F, Li L, Li Z, Jin Y, Liu W. Mesenchymal stem cells as a potential treatment for critically ill patients with coronavirus disease 2019. Stem Cells Transl Med. 2020;9(7):813-4. [CrossRef]

[40] Khoury M, Cuenca J, Cruz FF, Figueroa FE, Rocco PRM, Weiss DJ. Current status of cell-based therapies for respiratory virus infections: applicability to COVID-19. Eur Respir J. 2020; 55(6): 2000858. [CrossRef]

[41] Moore JB, June CH. Cytokine release syndrome in severe COVID-19. Science. 2020; 368(6490): 473-474. [CrossRef] 
[42] Rashidzadeh H, Danafar H, Rahimi H, Mozafari F, Salehiabar M, Rahmati MA, Rahamooz-Haghighi S, Mousazadeh N, Mohammadi A, Ertas YN, Ramazani A. Nanotechnology against the novel coronavirus (severe acute respiratory syndrome coronavirus 2): diagnosis, treatment, therapy and future perspectives. Nanomedicine. 2021;16(6):497-516. [CrossRef]

[43] Caracciolo M, Correale P, Mangano C, Foti G, Falcone C, Macheda S, Cuzzola M, Conte M, Falzea AC, Iuliano E, Morabito A. Efficacy and Effect of Inhaled Adenosine Treatment in Hospitalized COVID-19 Patients. Front Immunol. 2021; 12: 734. [CrossRef]

[44] Antonio AS, Wiedemann LM, Veiga-Junior VF. Natural products' role against COVID-19. RSC Advances. 2020; 10(39): 23379-93. [CrossRef]

[45] Ramaiah MJ. mTOR inhibition and p53 activation, microRNAs: The possible therapy against pandemic COVID19. Gene Rep. 2020; 20: 100765. [CrossRef]

[46] O'Driscoll L. Extracellular vesicles from mesenchymal stem cells as a Covid-19 treatment. Drug Discov Today. 2020; 25(7): 1124-1125. [CrossRef]

[47] Kumar S, Zhi K, Mukherji A, Gerth K. Repurposing Antiviral Protease Inhibitors Using Extracellular Vesicles for Potential Therapy of COVID-19. Viruses. 2020; 12(5): 486. [CrossRef]

[48] Muraca M, Pessina A, Pozzobon M, Dominici M, Galderisi U, Lazzari L, Parolini O, Lucarelli E, Perilongo G, Baraldi E. Mesenchymal stromal cells and their secreted extracellular vesicles as therapeutic tools for COVID-19 pneumonia?. J Control Release. 2020; 325: 135-40. [CrossRef] 